\title{
Animal Imagery in the Apocalypse
}

\author{
Blaise Gundu Gbaden, John Joshua Oyedemi \\ Department of Visual and Creative Arts Federal University Lafia P.M.B. 146, Lafia Nasarawa State Nigeria \\ Department of Fine and Applied Arts University of Jos Plateau State Nigeria
}

\begin{abstract}
The Renaissance was a fertile era for the rise of religious art mainly based on Biblical narratives from the Old and New testaments. Daunting imagery from the Book of Revelation (The Apocalypse) did not inspire the creation of many paintings. It was Albrecht Dürer (1471-1528) and William Blake (1757-1827) who produced several Biblical truths largely concentrating on the apocalyptic vision. This profound book contains a rich corpus of animal symbols, which provide challenging archetypes for contemporary painters in Nigeria and elsewhere. These have been presented in this paper chronologically in a lexicon; possible interpretations and analysis of the dense motifs are offered as guide to contemporary Nigerian painters and those interested in pursuing the merits of sacred art. Secondary sources of data have essentially informed the prognosis in this paper. The author acknowledges that this is an ongoing study and it is likely to be deepened when newer insights are gotten from further research.
\end{abstract}

Key Words: God, Christ, Renaissance, Sacred Art, Apocalypse, Angels, Woman, Dragon, Sulphur, Beast, Allegory

\section{Introduction}

Man's quest, from primordial times to date, has been the desire for visual discovery through art: an attempt to conquer reality via a mimesis of nature and illusion (Gombrich 1982). No period in human cultural history was more favourable to the growth of ideas than the renaissance. Originating in $14^{\text {th }}$ century Italy, the movement lasted into the $17^{\text {th }}$ century spreading throughout Europe. It was marked by a revival in the arts, literature and the beginnings of modern science. This era also inspired a flourishing in art based on Biblical themes.

In as much as the names Michelangelo (1475-1564), Raphael (1483-1520) and Rembrandt (1606-1669) recall the most profound of renaissance art, they also bequeathed to mankind the most prolific oeuvres of religious art. E.H. Gombrich's view is that this period developed convincing "illusionistic devices not so much as a general desire to imitate nature as a specific demand for the plausible narration of sacred events" (Gombrich 1982). Since inspiration was drawn from sacred scriptures a high form of artistic representation was created.

This paper does not aim to scrutinize the aspirations of naturalism in religious art but to present concise occurrences of art drawn directly from the spiritual pedigree, examine their application and then provide further areas of exploration essentially derived from the Book of the Revelation to St. John.

Also known as the Apocalypse ("apokalopsis" - Greek word for an uncovering or unveiling), this book belongs to the group of Jewish and Christian writings of $200 \mathrm{BC}$ to $\mathrm{AD} 150$, mostly anonymous. Full of symbolism, strong imagery and the expectation of Armageddon when God will destroy evil forces and restore the righteous to eternal life. It is the culmination of all Biblical prophecy, the point of convergence where they find their ultimate fulfillment. Regarded also as the history of humankind from the beginning to the end it reveals and clarifies God's truths and eternal purpose for man (Impe 1982).

Biblical narratives from the Old Testament, the Gospels, Acts and the Epistles abound but artists seem to have found the daunting imagery from the Apocalypse rather strong and indeed highly symbolic. Albrecht Dürer (1471-1528), artist of the reformation Germany, printed etchings of the "four horsemen of the apocalypse". Then of course paintings and sculptures of Angel Michael fighting the Dragon are popular. The more intense events have been largely ignored.

A cursory review of literature documenting religious art of Biblical significance from Genesis to Acts reveals quite an interesting corpus. The emphasis here is on animal forms as they appear in Biblical narratives and in art and their roles in the story of salvation. Can their potency be traced to good, that is Godly, intentions or to bad, that is

Satanic, manipulations? What is the relevance of animal metaphors in man's ascent to heavenly spheres apart from the obvious implication of angels' wings? How can we harness these images to improve our lives, our perception of spirituality, and our acceptance of art as a tool for experiencing hitherto unknown forces, principalities, evil spirits, demons, angels, servants of God and strange creatures that inhabit high unattainable realms? What place do animals occupy in Biblical revelation as a whole? 
The hypotheses can be overwhelming even for an artist who is merely interested in capturing on canvas pictures of Bible stories. Is it not superficial to reason that one can pick up the brush and recreate these narratives without a grasp of spiritual rectitude? William Blake, one of the greatest illustrators of Biblical truths may have been guided by a force that was certainly God like otherwise he could never possibly have produced awesome sacred images of unsurpassable dimensions (see Figs. 2 and 3 below).

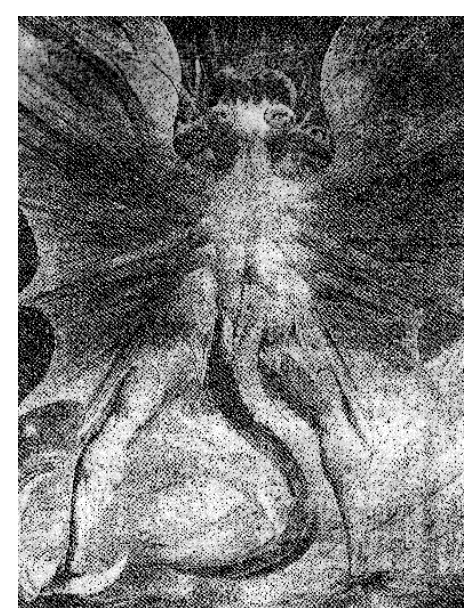

Fig. 1, William Blake, The Great Red Dragon and the Woman Clothed with the Sun, circa1803-05, Pen, Black Chalk, Watercolour, 43.5 x $34.5 \mathrm{~cm}$, (Source: Lister 1986)

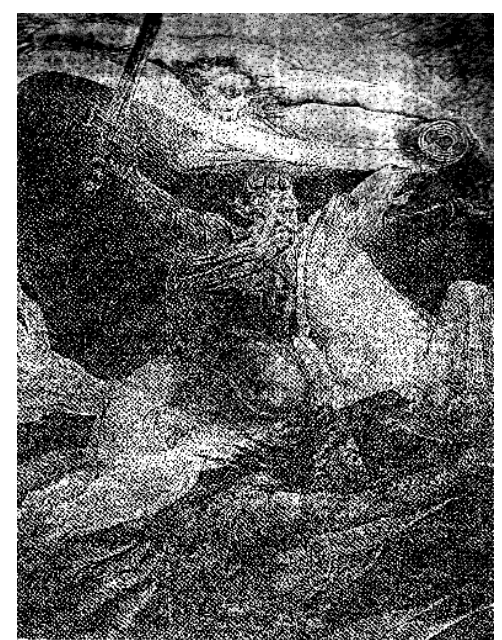

Fig. 2, William Blake, Death on a Pale Horse, circa1800, Pen and Watercolour over Pencil, 39.5 x $31.1 \mathrm{~cm}$, (Source: Lister 1986)

The first reference to animals in the Bible is found in Genesis 1:24 where the creation of animals on the sixth day precedes the creation of man later the same day. It is logical then that a serpent be responsible for the temptation of Eve. Dürer captures the moment succinctly for us in an etching depicting Adam and Eve in the Garden of Eden covering their nakedness with leaves while Lucifer is coiled up in the branches of the tree (Genesis 3:1-20) (see Fig. 3 below). 


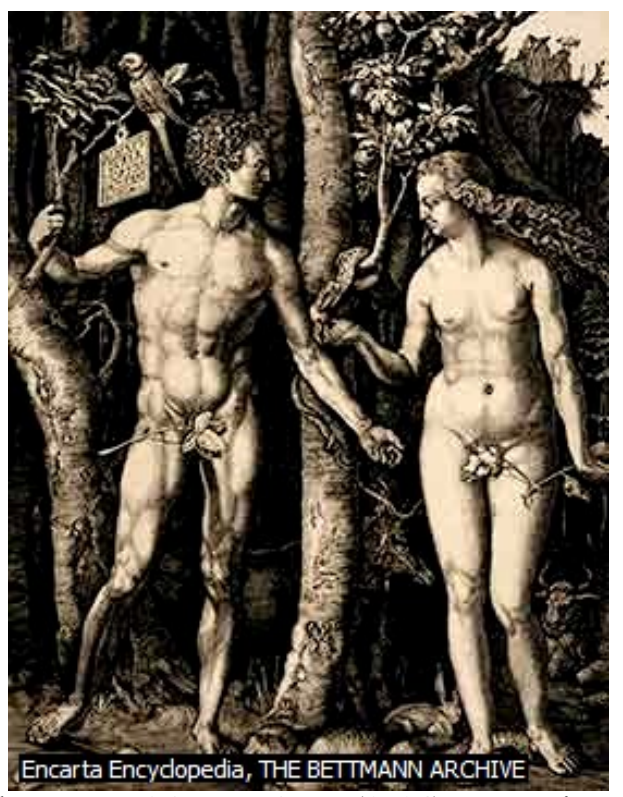

Fig. 1, Albrecht Dürer, Adam and Eve (1504), Engraving (Source: Encarta 2009)

Rembrandt's etching titled "Abraham entertaining the angels" (1656), captures the event described in Gen. 18:1-10 lucidly. Sarah is shown watching the three men from inside the tent while Abraham waits on them. He however does not know that they are angels. Of Isaiah's encounter, (Isaiah 6: 2-4) we are left in no doubt as to the fact that the "flaming creatures" are angels and that they bear wings; in this instance six each. Angels are included in this animal categorization for the simple fact that they bear wings, apparently with a semblance to those of eagles. No derogation is intended.

When the people of Israel got tired of waiting on Moses to return from Mount Sinai, where he had gone to receive the Ten Commandments they compelled Aaron to build a golden bull-calf made from gold trinkets and jewelry. This they worshipped amidst wild orgies of sex, drunkenness and feasting (Exodus 32:1-5). Another Old Testament passage that has left an indelible mark on this writer, and possibly others too, is the occasion when Elijah is taken up to heaven by horses of fire and chariots of fire (2Kings 2:11).

Several images of birds have been portrayed in the Old Testament passages. When the deluge ceased, the meek dove was sent by Noah to determine just how dry land was (Genesis 8:8-11). Ravens brought food to Elijah during a drought (1Kings 17:4). God gave the Israelites quails to eat at Taberah soon after they left Sinai (Numbers 11:31-32).

When next we encounter the image of the dove in the New Testament it represents the Holy Spirit descending from heaven upon Jesus Christ soon after his baptism from John at the Jordan (Matthew 3:16, Mark 1:10 and Luke 3:22). This fact hardly daunts Peter's belief as he is tested with the vision of animals, reptiles and wild birds which he is asked to take and eat. To him they are unclean and he rejects the proposition (Acts 10: 10-16).

\section{Animal Forms in The Apocalypse}

The animal forms as found in the Book of Revelation are presented here in chronological order. The roles ascribed to each of them as individuals or as a collective are then enumerated. Note that animal forms in some cases refer to creatures, beasts, humanoid or satanic beings. In this realm of existence these creatures have been apotheosised and are no more banal entities. The thesis by Impe (1982) forms a core articulation for the discourse below and several other sections of this paper.

The Four Living Creatures - Revelation 4:6-11 - The four living creatures have four distinct personalities but all perform the same duties. The first creature looks like a lion, the second like a bull, the third has a face like a man, and the fourth looks like an eagle in flight. Their bodies are covered with eyes in front and back. They have six wings each covered with eyes inside and out. They sing songs of glory and honour and thanks and praise ceaselessly to God so the twenty-four elders fall down and worship God day and night forever and ever.

The Lamb - Revelation 5:6-14 - The lamb has the appearance of having been killed. It has seven horns and seven eyes. These eyes represent the seven spirits of God. Through its sacrificial death it is worthy to break the seven seals on the scroll and open it. The blood of the lamb cleanses our sins. The lamb is the shepherd that leads his people to life giving waters. 
The Four Horsemen of the Apocalypse - Revelation 6:2-8 - The four horsemen are the contents of the first four seals of the scroll. The first horse is white; its rider holds a bow and wears a crown. It is a conqueror. The second one is a red horse; its rider holds a large sword. It is given power to bring war on earth, so humans can kill each other. The third horse is black; its rider holds a pair of scales. It is to pass judgment. The fourth horse is pale-coloured and bears a rider named death. He is accompanied by Hades. It is given authority over a quarter of the earth to kill using war, famine, disease and wild animals.

The Eagle - Revelation 8:13 - An eagle flies high in the air. Proclaims impending horror.

Locusts - Revelation 9:3-10 - The locusts are as large as horses ready for battle. On their heads they wear crowns of gold. Their faces arc those of men. They have hair like women's hair. Teeth like lions. Their chests are covered with iron breastplates. The sound of their wings is like many chariots engaged in a battle charge. Their tails are those of scorpions with stings. The locusts have the power to hurt and torment people with pain for five months without having to kill them.

Apollyon (Abaddon) - Revelation 9:11 - This angel is the king of the locusts and is in charge of the abyss (or bottomless pit). He is the destroyer.

The Plague Horses - Revelation 9:17-21 - The horse riders have breastplates red as fire, blue as sapphire and yellow as sulphur. The horses' heads look like lions' and their mouths spit fire, smoke and sulphur. Their tails are snakes that bite people. These horses are mandated to kill a third of humankind engulfed in demon worship, immorality and murders or stealing.

The Mighty Angel (Christ Himself?) - Revelation 10:1-3 - The mighty angel is wrapped in a cloud, with a rainbow halo, has a face like the sun. The legs are like pillars of fire and he stands astride the land and sea. When he speaks in his voice sounds like the roar of lions.

The Woman - Revelation 12:1-2, 4-6, 14-17 - The woman has a dress which is the sun; the moon is under her feet and a crown of twelve stars on her head. After giving birth to a son destined to rule the world with an iron rod, the child is taken away to God; she is given two wings of a large eagle to fly away to the desert for safety from the dragon (see below).

The Red Dragon - Revelation 12:3,4,7-9, 13-18 - The dragon is a huge red creature, has seven heads with a crown on each one and also bears ten horns. With the tail he drags a third of the stars out of the sky to the earth. His other names are Ancient Serpent, Devil or Satan, the Deceiver. A war breaks out in heaven between Angel Michael and his angels and the Dragon and his angels. Satan is defeated and thrown to the earth. He pursues the woman into the desert and when does not get her, commences to fight her descendants and destroy the human race.

The Two Beasts - Revelation 13:1-18 - The first beast has ten horns with a crown on each one, seven heads with names on them that are insulting God. The beast looks like a leopard with bear's feet, a mouth like a lion's mouth. One of his heads is fatally wounded but now appears healed. This beast has been given power by the dragon, it boasts and curses God. It fights and defeats God's people. Has authority over every tribe, nation, language or race. All living beings worship it. The second beast is called the false prophet has two horns like a lamb's horns, speaks like a dragon. This beast impersonates the lamb through miracles. Makes people worship the first beast, places marks (666) on people's foreheads by force.

The Frogs - Revelation 16:13-16 - The three unclean spirits look like frogs. They are spat out of the mouths of the beast, the dragon and the false prophet. They are spirits of demons that perform miracles and summon the entire kings of the world to come out for battle against the Kingdom of God.

The Famous Prostitute and the Beast - Revelation 17:1-18 - The prostitute is dressed in purple and scarlet and is covered with gold ornaments, precious stones and pearls. She holds a gold cup full of obscene and immoral things. On her forehead is written a name: "Great Babylon the mother of all the prostitutes and perverts in the world". She is drunk with blood of Jesus' followers. She sits on a red beast that has names insulting to God written all over it, has seven heads and ten horns. The seven heads are seven hills and seven kings who are ruling the earth. The ten horns are ten kings about to rule and fight the lamb and his faithful. They will be defeated. They will in turn kill the prostitute and eat her flesh.

The White Horse (Rider is Christ Jesus) - Revelation 19:11-16 - The white horse bears a rider who is called faithful and true and "The word of God". Eyes like a flame of fire, he has many crowns on his head. A name is written on him only he can decipher. His robe is covered with blood. He leads the armies of heaven who ride on white horses and are dressed in clean white linen. A sharp sword issues forth from his mouth to defeat the nations. He rules with an iron rod. On his robe and thigh are written the name "King of Kings and Lord of Lords".

The Fate of the Evil Ones - Revelation 19:19-21; 20:10 - After the battle between the beast and his armies and the white horse rider and his armies, the beast is defeated. The beast, Satan and fake prophets are thrown into the pit of sulphur where they will be tormented day and night forever and ever. 


\section{Critical Analysis}

In analysing apocalyptic symbolism, visions of the prophets Daniel, Ezekiel and Isaiah as contained in the Bible are taken into cognisance. Note too that the tribulations mentioned in Matthew 24, Mark 13 and Luke 17 prefigure these end time events.

The Four Living Creatures - The word beast is "Zoon" in Greek, meaning "a living creature", indicating created entities. The symbolic and figurative expressions denote their strength and knowledge. Their eyes placed all over the body enable them to see all things clearly and with accuracy. In Isaiah 6:1-13 these beings arc called seraphim (or angels of God) created to praise, exalt and adulate the Lord. They are beautiful. Impe (1982) alludes that they represent leadership: Lion is leader of wild beasts, the bull (ox or cow) leads domesticated animals, the eagle leads the birds, while man leads all creatures. These four creatures, which appear in Ezekiel 1:1-28 are in fact the precursor to those of the Book of Revelation. Lister (1986) shows that they are also related to the four standard iconographical symbols of the Evangelists: a man - Matthew; a lion Mark; an Ox - Luke; an eagle - John.

The Lamb - The Lamb is Christ Jesus. The seven horns picture strength, authority. With the seven eyes he sees all things. The number seven means perfection; God's number of perfection. The seven spirits full of the Holy Spirit.

The Four Horsemen of the Apocalypse - The four horsemen are signs of the emanation of the second coming. The first rider on white horse is a counterfeit of Jesus, (Anti-Christ), Satan trying to deceive mankind, because Jesus rides on a white horse as King of Kings and Lord of Lords (See Rev. 19:11, Matt. 24:3). The rider on red horse represents wars and rumours of wars. The third rider on black reflects mass starvation, famines (as in Matt. 24:7). Fourth rider on pale horse accompanied by Hades stands for pestilence, earthquakes, destruction, death, hunger. The Anti-Christ's crown represents diplomacy. The red horse is Red Russia.

Locusts - These locusts are fallen angels. The horses denote strength and speed; gold crowns - royalty, conquerors; faces of men - intelligence; hair of women - attractiveness; teeth of lions - cruelty; breastplates of iron - invincibility; chariots - calamity.

The Mighty Angel - He is Christ. Cloud shows presence of Christ

The Woman - Represents Israel ? (Not Mary ?). Gives birth to Jesus Christ.

The Red Dragon - Is Satan. Seven heads depict wisdom. Satan is full of wisdom, as he was created perfect. The ten horns are universal power, universal control, and international power. The stars of heaven refer to angels.

The Two Beasts - Represent world powers; a lion - Babylon; a bear - Medopersia; a leopard -Greece; a beast - Rome. The wounds mean death but restoration to life follows.

The Frogs - Represent uncleanliness brought about by a false trinity of Satan, Anti-Christ and false prophet imitating the Holy Trinity.

The Famous Prostitute - This symbolises spiritual fornication, idolatry, embracing religions of the world. The woman is world church, denoting doctrinal incorrectness. Purple and scarlet is rulership of church and temporal powers. Gold ornaments stand for wealth. The seven heads refer to Rome with its seven hills: Aventine, Caelian, Capitoline, Esquiline, Palatine, Ovirinal, and Viminal. The five kings are: Julius Caesar, Tiberius, Caligula, Claudius and Nero. The sixth king Domitan reigns in John's time while the seventh is yet to come but is the Anti-Christ. Waters refers to world church.

\section{Colour Analysis}

Vibrant colours are critical to the revelation story.

White - horse, cloud, robes, linen and the Lamb have been depicted in white as assignations of Godliness and cleanliness.

Red - blood, fire, war, horse, the slain lamb, warriors' breastplates, lions, the mighty angel's legs, the dragon and the beast are variously red.

Black - judgement, darkness, doom. One of the four horses is black with its rider.

Pale - death, Hades, deficiency, negating, disease, wildness. Horse form appears black.

Blue - denotes preciousness, openness, limitless, air. The rainbow, the sea, sky, smoke and sapphire bear this colour.

Yellow - sometimes referred to as sulphur is the colour of burning hell, the bottomless pit, the deep abyss.

Purple and Scarlet - are royal colours embodying royalty, leadership, temporal power, diplomacy; also depths of the heavenly regions.

\section{The Elements}

Some of the most valued elements on earth have found expression in the apocalyptic narration.

Sulfur - is yellowish element and burns hot causing devastation. It is quite appropriate that it constitutes hell fire. Ironically however there is a fish in the cold depths of the ocean that feeds on sulfur. This hardly reduces its efficacy. 
Sapphire - a precious blue stone is used in this context to depict the high rank of the army of locusts.

Gold - a precious metal that never rusts. It has been used as a symbol of affluence and wealth. The element crowns are made of. It is ancient and ageless.

Iron - available in most parts of the world, is used as armour and battle dress. It is the element for fashioning weapons of warfare. It is resilient and can stand pressure. Has firmness of purpose. Represents discipline.

Fire - consumes anything in its path. It is the element that would be used to destroy the sinful at the end of time. Jesus' eyes are a flame of fire. It is an ancient awesome element and along with water and air were said to constitute life force by the earliest philosophers of science.

Scales - are probably made of silver, brass, bronze or burnished iron. Symbol of judgment and the rule of law, justice and equity. Here the colour black is associated with it: denotes neutrality?

Stars - on one level form the heavenly constellations, they describe the angelic beings, both the faithful ones and the fallen ones. Twelve stars form the crown for the woman (Mary ?) who gives birth to the Messiah.

Bow - as a war implement denotes conquest perhaps by force.

God.

Sword - denotes the right to defeat rivals, rule nations; also to show path to righteousness. The word of darkness.

Smoke - goes forth as precursor of fire or consequence of disaster or distraction. Associated with

Sun - radiates holiness and hope and godliness. $\mathrm{h}$ is the cloak for the Messiah's mother. The Christ figure's face radiates the essence of the sun.

Rainbow Halo - denotes presence of the Christ figure. Holy assignation of perfection.

Cloud - denotes heavenly presence.

Horns - the spirit beings that bear horns are both the good and evil ones as they all have the same origin. At the final judgment the evil will be burnt with sulfur fires in the abyss.

Desert - land of refuge, fasting and prayer; a place of temptations, repentance, where people wait for restoration to salvation.

666 - is the mark of the beast.

7 - the number of God's perfection and perfect creation.

White Linen - robe of the Christ saviour and uniform of his army. Note too that Jesus is laid to rest in white linen. Here in the Book of Revelation his robe is covered with blood.

Chariots - denote battle charge. Are horse drawn and cause devastation. Very effective weapons of war.

Precious stones - would include all known precious stones and pearls. Denote royalty and wealth.

Water - represents the world churches and the confusion they are in; also the water physically make up the seas. Also gives life as at baptism.

Moon - heavenly element associated with the Messiah's mother and goodness. She stands on the moon.
A - angels
B - bear, beasts, blood, bulls
C - creatures
D - demons, devils, dragons
E - eagles, eyes
F - faces, frogs
H - heads, hair, horns, horses, human form
L - lambs, leopards, locusts
M - man form
S - Satan, scorpions, serpents, snakes
T - tails, teeth
W - wings, woman

\section{Glossary of Animal Forms}

\section{Conclusion}

It is commendable that the visual artist search for imagery for artistic expression from diverse sources: geographic, emotional, climatic, biological, environmental or even sub-conscious; the more unusual the origin of the source, the more exciting the results from the experience. This paper has attempted an extraction of animal motifs from the Book of Revelation as contained in the Holy Bible. This is admittedly a religious or more appropriately a sacred genre. The intention is to expand the existing range of archetypes for more advanced exploration into articulation of visual symbolism and then propagate more coherent values in 
qualitative artistic productivity. On this level the paper aspires to improve knowledge in the appreciable area of sourcing for enduring archetypes.

Tentative answers to the hypothetical enumerations in the introductory segment of this paper can now be attempted, not necessarily with finality as the levels of perception and interpretation inevitable vary. These animal forms are potent as they bear crucial elements for the apocalyptic age, which no other imagery can convincingly convey.

First, their organic nature enables them to morph from one form to another; assuming different animal characteristics, suiting the specificity of the messages transmitted. Secondly, these animals are familiar ones; some domesticated, others from the wild, but still known to universal man, the final recipient of the revelations.

Thirdly, a common trend of adaptability runs through all the animals. They are to be found at different climatic regions of the earth and in the atmosphere above it: the eagle is lord of the skies; the lion rules the savannahs and sahelian lands; the bear lives in the temperate areas; the horse just like man is everywhere, etc.

It is interesting to note that these animals possess the capacity to impersonate. The bad impersonate the good as good does not conceive evil. This ability points to their common origin. Satan was created a perfect being; his angels are imbued with his powers to imitate spiritual conditions and deceive the undiscerning.

The Book of Revelation is an animal allegory of the conflict between good and evil. Animal forms with their strength and resilience are best suited to tell the story. The acceptance of the prominent role animals play in man's ultimate ascent to the heavenly realms or his unfortunate demise into the deep abyss has now overshadowed the old erroneous notion that animals do not possess souls.

There is a historical link between the animal imagery of the Apocalypse and that of the Old Testament dispensation. That Noah built an ark during the Flood and saved all animal species rather than man is a pointer to their relevance. As illuminated in the literature reviews cited in this paper, animals feature prominently throughout man's history of salvation to the extent that the Holy Spirit is visualised as a White Dove.

It is not unambiguous to harness Biblical imagery of animal forms, as exemplified in the Book of Revelation, to create artistic forms, which will guide man towards attaining spiritual excellence. Only art can recreate the most intriguing Bible passages and bring them to visibility thus clarifying the mind of its relevance.

For the artist to interpret visions of such spiritual magnitude for mankind however deep immersion in Biblical spiritual values are recommended. This will prevent false doctrine being spread and yet draw us closer to the truth.

As artists of African origin, essentially, go into this level of perception it would help lo erode the several images interpreting Bible passages, which show Christ as a European white male. If those Western artists painted for their western audience it is to be expected that the imagery would definitely be white to relate to their social values. When Africans plunge into this agenda their art will now take cognizance of their societal values too. Ultimately the place of sacred values will then be brought closer home into African hearts. And art of course, being our primary concern would improve for the better and become even more prominent in our daily lives.

In conclusion, it is hoped that this paper has provided imagery for artistic adventure and more essentially has opened a door to exploration of artistic forms, even if from an unusual source. Let artists harness it. The study is not conclusive and as new ideas are discovered in this direction the work would be expanded.

\section{References}

[1]. Bomford. D., et al. (Eds.). (1990). Art in the Making: Impressionism. London: National Gallery Publications.

[2]. Dunbar, B.L. "Albrecht Dürer." Microsoft ${ }^{\circledR}$ Encarta ${ }^{\circledR} 2009$ [DVD]

[3]. Gombrich, E.H. (1985). Norm and Form: Studies in the art of the Renaissance, 4th edition. London: Phaidon.

[4]. Gombrich, E.H. (1982). The Image and the Eye. Oxford: Phaidon. Pp. 11, 20

[5]. Impe, J. (1982). Revelation Revealed Verse by Verse. Michigan: Jack Van Impe Ministries.

[6]. Lister, R. (1986). The Paintings of William Blake. Cambridge: Cambridge University Press.

[7]. Strong, J. (1995). The New Strong's Exhaustive Concordance of the Bible. Nashville: Thomas Nelson.

[8]. White, C. (1989). Rembrandt. London: Thames and Hudson. 